\title{
La Academia Nacional de Medicina de Costa Rica y la obtención de células madres para curar enfermedades
}

\author{
Claudio Orlich Carranza
} ' Presidente Academia Nacional de
Medicina
ISSN 0001-6002/2004/46/2/56

Acta Médica Costarricense,(C2004

Colegio de Médicos y Cirujanos
Para cuidar la salud o atender una enfermedad, se requiere combinar medidas educativas y preventivas, en procura de corregir malos hábitos y vacunar a la población con tratamientos médicos muy diversos. En el futuro, además contaremos con una medicina basada en el empleo de genes para evitar la aparición de enfermedades genéticas, e incluso del cáncer. También se investiga el uso de células madres embrionarias y adultas para regenerar tejidos enfermos o para sustituirlos, creando órganos para trasplantes, uno de los problemas más graves en el mundo.

Un grupo de diputados pretende proponer una ley que prohíba la clonación humana, posición con la que coincidimos por completo; sin embargo, dicha ley trae aparejada la prohibición de obtener células madres embrionarias para investigar y crear tejidos (clonación terapéutica), lo que consideramos necesario, pues de ninguna forma con esta técnica se pretende crear un ser humano, sino, únicamente, permitir in vitro y no in vivo, obtener células madres con el fin de, si esta técnica da resultados, disponer de piel para los quemados, insulina para los diabéticos, células nerviosas para combatir la enfermedad de Parkinson y Alzheimer, ayudar a los paralíticos con lesiones en la columna, etc.

Científicos alrededor del mundo, así como Premios Nobel e instituciones de prestigio mundial, como la Academia de Ciencias de los Estados Unidos, han señalado: "Que debe hacerse una diferenciación entre producir un ser humano por clonación, a lo que todos se oponen, a tratar de producir células humanas para curar enfermedades en el ser humano, con lo que sí están de acuerdo".

El Instituto de Salud de Estados Unidos y la Fundación Europea para la Ciencia han referido que no se sabe aún si las células madres de adultos se comportarán igual que las embrionarias. Lo que está claro es que es imprescindible investigar en ambas líneas para tomar una decisión en el futuro. Si estos estudios comparativos se impidieran, renunciaríamos a la posible mejor oportunidad que tenemos para curar innumerables enfermedades graves de la población mundial.

Nuestra Academia considera que si las células madres adultas demuestran ser mejores o iguales que las células madres embrionarias, y proporcionan todo tipo de tejidos, se debería emplear solamente estas, con el fin de evitar los dilemas religiosos que el uso de las embrionarias genera en algunos grupos. Sin embargo, mientras estas pruebas no se realicen, es imposible afirmar cuál tipo de estas células será la más adecuada para el futuro de la medicina, de modo que, mientras tanto, se debe permitir la clonación terapéutica, no así la humana.

El motivo por el cual la Academia Nacional de Medicina de Costa Rica se pronuncia al respecto, obedece a la obligación mundial existente, para toda academia científica, de honrar el compromiso de apoyar la investigación, asegurando su libertad, indispensable para el progreso de la ciencia y la medicina.

Nunca se justifica la imposición de un punto de vista. Como lo señala Kart Popper, la sociedad abierta es la que permite la crítica interna y la oposición, de ahí su progreso; en cambio, las sociedades cerradas, en donde se impone el criterio de una minoría poderosa, se estancan, ya que sin libertad no es posible el avance del conocimiento humano, y en especial, del científico, que se encuentran en perpetuo cambio. 